\title{
DR2004032
}

TABLE DR1. COSMOGENIC NUCLIDE DATA, BURIAL AGES, PRE-BURIAL EROSION RATES, AND RIVER INCISION RATES FROM SIERRA NEVADA CAVES

\begin{tabular}{|c|c|c|c|c|c|c|c|c|}
\hline Cave & River & $\begin{array}{l}\text { Elev. } \\
(\mathrm{m})^{*}\end{array}$ & $\begin{array}{c}{ }^{26} \mathrm{Al} \\
\left(10^{4} \mathrm{~atm} / \mathrm{g}\right)\end{array}$ & $\begin{array}{c}{ }^{10} \mathrm{Be} \\
\left(10^{4} \mathrm{~atm} / \mathrm{g}\right)\end{array}$ & ${ }^{26} \mathrm{Al} /{ }^{10} \mathrm{Be}$ & $\begin{array}{c}\text { Burial age } \\
(\mathrm{Ma}) \dagger\end{array}$ & $\begin{array}{c}\text { Pre-burial erosion } \\
(\mathrm{mm} / \mathrm{yr}) \S\end{array}$ & $\begin{array}{l}\text { Incision } \\
(\mathrm{mm} / \mathrm{yr})\end{array}$ \\
\hline $\begin{array}{l}\text { Crystal } \\
\text { Stanislaus }\end{array}$ & $\begin{array}{l}\text { Middle Fk } \\
\text { Stanislaus }\end{array}$ & $92 \pm 5$ & $26.56 \pm 0.98$ & $10.28 \pm 0.21$ & $2.59 \pm 0.11$ & $\begin{array}{c}1.63 \pm 0.08 \\
(0.16)\end{array}$ & $\begin{array}{c}0.046 \pm 0.003 \\
(0.010)\end{array}$ & 0.058 \\
\hline Bat & $\begin{array}{l}\text { South Fk } \\
\text { Kings }\end{array}$ & $395 \pm 2$ & $11.15 \pm 0.93$ & $6.64 \pm 0.16$ & $1.48 \pm 0.16$ & $\begin{array}{c}2.70 \pm 0.21 \\
(0.38)\end{array}$ & $\begin{array}{c}0.079 \pm 0.006 \\
(0.016)\end{array}$ & 0.271 \\
\hline Boyden & $\begin{array}{l}\text { South Fk } \\
\text { Kings }\end{array}$ & $42.5 \pm 1$ & $36.41 \pm 1.36$ & $12.43 \pm 0.30$ & $2.93 \pm 0.13$ & $\begin{array}{c}1.40 \pm 0.08 \\
(0.15)\end{array}$ & $\begin{array}{c}0.078 \pm 0.005 \\
(0.017)\end{array}$ & 0.021 \\
\hline Bear & $\begin{array}{l}\text { South Fk } \\
\text { Kings }\end{array}$ & $8 \pm 1$ & $56.24 \pm 2.61$ & $10.92 \pm 0.28$ & $5.15 \pm 0.22$ & $\begin{array}{c}0.32 \pm 0.10 \\
(0.18)\end{array}$ & $\begin{array}{c}0.163 \pm 0.012 \\
(0.035)\end{array}$ & 0.023 \\
\hline $\begin{array}{l}\text { Weis } \\
\text { Raum }\end{array}$ & $\begin{array}{l}\text { Yucca } \\
\text { Creek }\end{array}$ & $212 \pm 2$ & $9.46 \pm 0.75$ & $5.50 \pm 0.12$ & $1.72 \pm 0.14$ & $\begin{array}{c}2.42 \pm 0.16 \\
(0.28)\end{array}$ & $\begin{array}{c}0.055 \pm 0.005 \\
\quad(0.012)\end{array}$ & 0.115 \\
\hline $\begin{array}{l}\text { Hurricane } \\
\text { Crawl }\end{array}$ & $\begin{array}{l}\text { Yucca } \\
\text { Creek }\end{array}$ & $39.5 \pm 1$ & $35.23 \pm 1.93$ & $9.44 \pm 0.24$ & $3.73 \pm 0.23$ & $\begin{array}{c}0.93 \pm 0.12 \\
(0.24)\end{array}$ & $\begin{array}{l}0.064 \pm 0.005 \\
\quad(0.014)\end{array}$ & 0.042 \\
\hline $\begin{array}{l}\text { Crystal } \\
\text { (Bear } \\
\text { Den) }\end{array}$ & $\begin{array}{l}\text { Yucca } \\
\text { Creek }\end{array}$ & $58 \pm 1$ & $97.53 \pm 4.10$ & $29.81 \pm 0.70$ & $3.27 \pm 0.16$ & $\begin{array}{c}1.17 \pm 0.09 \\
(0.16)\end{array}$ & $\begin{array}{l}0.021 \pm 0.001 \\
\quad(0.005)\end{array}$ & 0.179 \\
\hline $\begin{array}{l}\text { Crystal } \\
\text { (Phosph. } \\
\text { Room) }\end{array}$ & $\begin{array}{l}\text { Cascade } \\
\text { Creek }\end{array}$ & $36.5 \pm 1$ & $311.9 \pm 8.7$ & $91.8 \pm 2.6$ & $3.39 \pm 0.14$ & $\begin{array}{c}1.05 \pm 0.08 \\
(0.15)\end{array}$ & $\begin{array}{c}0.007 \pm 0.0004 \\
(0.001)\end{array}$ & 0.108 \\
\hline $\begin{array}{l}\text { Crystal } \\
\text { (Marble } \\
\text { Hall) }\end{array}$ & $\begin{array}{l}\text { Cascade } \\
\text { Creek }\end{array}$ & $22.5 \pm 1$ & $79.17 \pm 3.41$ & $20.47 \pm 0.49$ & $3.87 \pm 0.19$ & $\begin{array}{c}0.86 \pm 0.09 \\
(0.16)\end{array}$ & $\begin{array}{c}0.035 \pm 0.002 \\
\quad(0.007)\end{array}$ & 0.046 \\
\hline $\begin{array}{l}\text { Crystal } \\
\text { (Junction } \\
\text { Room) }\end{array}$ & $\begin{array}{c}\text { Cascade } \\
\text { Creek }\end{array}$ & $8.5 \pm 1$ & $107.2 \pm 3.5$ & $23.79 \pm 0.56$ & $4.51 \pm 0.18$ & $\begin{array}{c}0.56 \pm 0.08 \\
(0.15)\end{array}$ & $\begin{array}{l}0.034 \pm 0.003 \\
\quad(0.009)\end{array}$ & 0.015 \\
\hline Clough & $\begin{array}{c}\text { South Fk } \\
\text { Kaweah }\end{array}$ & $53.5 \pm 2$ & $7.33 \pm 0.61$ & $2.09 \pm 0.07$ & $3.51 \pm 0.31$ & $\begin{array}{c}1.06 \pm 0.17 \\
(0.30)\end{array}$ & $\begin{array}{c}0.354 \pm 0.026 \\
(0.075)\end{array}$ & 0.050 \\
\hline New & $\begin{array}{l}\text { South Fk } \\
\text { Kaweah }\end{array}$ & $34 \pm 2$ & $54.44 \pm 2.44$ & $13.85 \pm 0.33$ & $3.93 \pm 0.20$ & $\begin{array}{c}0.83 \pm 0.10 \\
(0.18)\end{array}$ & $\begin{array}{c}0.059 \pm 0.004 \\
(0.013)\end{array}$ & 0.040 \\
\hline $\begin{array}{l}\text { Soldiers } \\
\text { (Entrance } \\
\text { passage) }\end{array}$ & $\begin{array}{l}\text { South Fk } \\
\text { Kaweah }\end{array}$ & $83 \pm 2$ & $50.24 \pm 3.24$ & $15.94 \pm 0.38$ & $3.15 \pm 0.22$ & $\begin{array}{c}1.25 \pm 0.13 \\
(0.20)\end{array}$ & $\begin{array}{l}0.038 \pm 0.003 \\
\quad(0.008)\end{array}$ & 0.155 \\
\hline $\begin{array}{l}\text { Soldeirs } \\
\text { (Waiting } \\
\text { Room) }\end{array}$ & $\begin{array}{l}\text { South Fk } \\
\text { Kaweah }\end{array}$ & $41 \pm 2$ & $71.36 \pm 2.97$ & $19.63 \pm 0.49$ & $3.64 \pm 0.18$ & $\begin{array}{c}0.98 \pm 0.09 \\
(0.17)\end{array}$ & $\begin{array}{c}0.035 \pm 0.002 \\
(0.005)\end{array}$ & 0.049 \\
\hline $\begin{array}{l}\text { Soldiers } \\
\text { (Lower } \\
\text { Corridor) }\end{array}$ & $\begin{array}{l}\text { South Fk } \\
\text { Kaweah }\end{array}$ & $12.5 \pm 2$ & $73.93 \pm 3.21$ & $15.03 \pm 0.36$ & $4.92 \pm 0.24$ & $\begin{array}{c}0.40 \pm 0.09 \\
(0.17)\end{array}$ & $\begin{array}{c}0.059 \pm(0.004) \\
(0.010)\end{array}$ & 0.031 \\
\hline $\begin{array}{l}\text { Modern } \\
\text { river } \\
\text { sediment }\end{array}$ & $\begin{array}{l}\text { South Fk } \\
\text { Kings }\end{array}$ & $0 \pm 0$ & $22.68 \pm 1.17$ & $3.61 \pm 0.07$ & $6.26 \pm 0.35$ & $\begin{array}{c}-0.06 \pm 0.11 \\
(0.21)\end{array}$ & $\begin{array}{l}0.508 \pm 0.038 \\
\quad(0.108)\end{array}$ & - \\
\hline $\begin{array}{l}\text { Modern } \\
\text { river } \\
\text { sediment }\end{array}$ & $\begin{array}{l}\text { Middle Fk } \\
\text { Kaweah }\end{array}$ & $0 \pm 0$ & $35.25 \pm 1.65$ & $5.90 \pm 0.16$ & $5.97 \pm 0.32$ & $\begin{array}{c}0.04 \pm 0.10 \\
(0.18)\end{array}$ & $\begin{array}{c}0.202 \pm 0.015 \\
(0.043)\end{array}$ & - \\
\hline
\end{tabular}

sediment

\footnotetext{
*Reported elevations are sample elevations above local modern rivers. Where multiple caves exist in canyon walls, we use the elevation between caves to calculate incision rates; for example, the distance between Weis Raum Cave and Hurricane Crawl Cave (172.5 m) is used to calculate the incision rate for the period 2.42 to $0.93 \mathrm{Ma}$.

$\dagger$ We calculated burial ages and pre-burial erosion rates using equations in (Granger et al., 2001). Uncertainties represent one standard error measurement uncertainty, with systematic uncertainties in production rates $(20 \%),{ }^{26} \mathrm{Al} /{ }^{10} \mathrm{Be}$ production ratio (Stone, 2000) and radioactive decay constants (Norris et al., 1983; Hofmann et al., 1987) added in quadrature and shown in parentheses.

$\S U n l i k e{ }^{26} \mathrm{Al} /{ }^{10} \mathrm{Be}$ burial ages, pre-burial erosion rates are sensitive to production rates that scale with altitude and latitude. We used sea level, high-latitude production rates for ${ }^{26} \mathrm{Al}$ and ${ }^{10} \mathrm{Be}$ of 31.1 and $5.1 \mathrm{~atm} / \mathrm{g} / \mathrm{yr}$, respectively (Stone, 2000), and corrected for latitude and altitude (Dunai, 2000). Because the caves draw sediment from drainage basins with hundreds to thousands of meters of local relief, and because we have no knowledge of where within these basins the coarse clasts we sampled originated from, we scaled production rates using the mean altitude of the modern basin upstream of the caves. Accounting for the possible range of source altitudes leads to additional total uncertainty in pre-burial erosion rates.
} 
TABLE DR2. COSMOGENIC NUCLIDE DATA, EROSION RATES, AND EXPOSURE AGES FOR SOUTHERN SIERRA NEVADA INTERFLUVE SURFACES

\begin{tabular}{|c|c|c|c|c|c|c|c|c|}
\hline Sample & $\begin{array}{l}\text { Elev. } \\
(\mathrm{m})\end{array}$ & $\begin{array}{c}{ }^{26} \mathrm{Al} * \\
\left(10^{6} \mathrm{~atm} / \mathrm{g}\right)\end{array}$ & $\begin{array}{c}{ }^{10} \mathrm{Be}^{*} \\
\left(10^{6} \mathrm{~atm} / \mathrm{g}\right)\end{array}$ & ${ }^{26} \mathrm{Al} /{ }^{10} \mathrm{Be}$ & $\begin{array}{c}{ }^{26} \mathrm{Al} \text { erosion } \dagger \\
(\mathrm{mm} / \mathrm{yr})\end{array}$ & $\begin{array}{c}{ }^{10} \text { Be erosion } \dagger \\
(\mathrm{mm} / \mathrm{yr})\end{array}$ & $\begin{array}{c}{ }^{26} \text { Al age } \dagger \\
(\mathrm{kyr})\end{array}$ & $\begin{array}{c}{ }^{10} \text { Be age } \dagger \\
\text { (kyr) }\end{array}$ \\
\hline HR-1 & 1975 & $42.85 \pm 1.58$ & $8.12 \pm 0.18$ & $5.28 \pm 0.23$ & $0.014 \pm 0.003$ & $0.013 \pm 0.002$ & $41.7 \pm 9$ & $45.7 \pm 9$ \\
\hline BR-1 & 1948 & $143.14 \pm 4.96$ & $28.17 \pm 0.59$ & $5.08 \pm 0.21$ & $0.004 \pm 0.001$ & $0.003 \pm 0.001$ & $144.6 \pm 31$ & $163.2 \pm 34$ \\
\hline BVD-1 & 2294 & $38.74 \pm 1.35$ & $6.85 \pm 0.19$ & $5.66 \pm 0.25$ & $0.020 \pm 0.004$ & $0.019 \pm 0.004$ & $29.3 \pm 6$ & $30.7 \pm 6$ \\
\hline Mean & & & & & $0.012 \pm 0.005$ & $0.012 \pm 0.005$ & $71.9 \pm 33$ & $79.9 \pm 36$ \\
\hline
\end{tabular}

*We used ${ }^{26} \mathrm{Al}$ and ${ }^{10} \mathrm{Be}$ production rates of 31.1 and 5.1 atoms $\mathrm{g}^{-1} \mathrm{yr}^{-1}$, respectively (Stone, 2000), and corrected for latitude, altitude (Dunai, 2000) and topographic shielding (Dunne et al., 1999).

$\dagger$ Uncertainties in erosion rates and exposure ages are propagated from measurement uncertainty, plus systematic uncertainties in production rates (20\%), attenuation coefficients (Lal, 1991), and radioactive decay constants (Norris et al., 1983; Hofmann et al., 1987).

\section{APPENDIX 1: METHODS}

\section{Field methods}

Sierra Nevada caves present an ideal setting for cosmogenic burial dating, as quartz-rich sediments are eroded primarily from the granitic batholith upstream and are carried rapidly into caves. We sampled only from isolated cave passages with clear relations to former river levels. We sampled well-rounded gravel and cobbles, predominantly of granitic composition, from coarse, well-sorted, clast-supported deposits indicative of river bedload. By dating bedload material, we most accurately record when caves were at river level. Although sediment burial ages are necessarily minimum cave ages (resulting in maximum river incision rates) they provide better estimates of cave ages than other available methods. Although we do not report our results here, we find that both sediment paleomagnetism and ${ }^{234} \mathrm{U} /{ }^{230} \mathrm{Th}$ basal ages on speleothems consistently underestimate the ages of Sierra Nevada caves. This is primarily because sediment accumulation is not constant, a necessary assumption for paleomagnetism, and because initiation of speleothem growth may significantly lag cave development. Similar conclusions were reached in a study of Mammoth Cave deposits (Granger et al., 2001).

\section{Laboratory methods}

To determine ${ }^{26} \mathrm{Al}$ and ${ }^{10} \mathrm{Be}$ concentrations, we first crushed and sieved samples to $0.25-0.5$ $\mathrm{mm}$, and purified $\sim 75 \mathrm{~g}$ of quartz from each sample by selective chemical dissolution (Kohl and Nishiizumi, 1992). We spiked each sample with $\sim 0.4 \mathrm{mg}{ }^{9} \mathrm{Be}$ in a carrier solution prepared from 
deep-mined beryl $\left({ }^{10} \mathrm{Be} /{ }^{9} \mathrm{Be}=2.98 \times 10^{-15}\right)$. We then dissolved the quartz in $\mathrm{HF}$ and $\mathrm{HNO}_{3}$. After expelling fluorides with $\mathrm{HClO}_{4}$, we separated and purified $\mathrm{Al}$ and $\mathrm{Be}$ by ion exchange chromatography and selective precipitation as hydroxides. We dried the precipitates, oxidized them at $1100^{\circ} \mathrm{C}$, and mixed the resulting oxides with $\mathrm{Ag}$ (for $\mathrm{Al}$ ) and $\mathrm{Nb}$ (for $\mathrm{Be}$ ) powders. We determined the ${ }^{10} \mathrm{Be} /{ }^{9} \mathrm{Be}$ and ${ }^{26} \mathrm{Al} /{ }^{27} \mathrm{Al}$ by accelerator mass spectrometry at Lawrence Livermore National Laboratory (LLNL), and normalized these measurements to LLNL ${ }^{10} \mathrm{Be}$ secondary standards calibrated against an $\mathrm{ICN}{ }^{10} \mathrm{Be}$ standard $\left(\mathrm{t}_{1 / 2}=1.5 \times 10^{6} \mathrm{y}\right.$.) prepared by K. Nishiizumi and against a NIST ${ }^{26} \mathrm{Al}\left(\mathrm{t}_{1 / 2}=7.05 \times 10^{5} \mathrm{y}\right.$.) standard prepared by K. Nishiizumi. We corrected sample concentrations for process blanks; mean process blanks were low $\left({ }^{26} \mathrm{Al} /{ }^{27} \mathrm{Al}=9.24 \times 10^{-15}\right.$,

${ }^{10} \mathrm{Be} /{ }^{9} \mathrm{Be}=4.04 \times 10^{-15}$ ) compared to samples. We measured stable aluminum concentrations by optical emission spectrometry (ICP-OES) at UC Santa Cruz and assigned 5\% error to these measurements.

\section{Numerical model}

We modeled the incision history of the South Fork of the Kings River in response to tectonic and climatic perturbations using a one-dimensional, finite difference, stream-power based model of river profile evolution. The rate of channel erosion $d z / d t$ is:

$$
\frac{d z}{d t}=\frac{K Q}{W} \frac{d z}{d x}
$$

where $Q$ is river discharge, $d z / d x$ is river slope, $K$ is an erosional coefficient that represents rock resistance to erosion, and $\mathrm{W}$ is channel width. We determined $Q$ using published values of precipitation across the range, and using the contributing area as a function of downstream distance for the South Fork Kings River, determined from digital elevation models using Rivertools ${ }^{\mathrm{TM}}$ software. We measured channel widths at several points along the river profile to constrain a power-law relationship of channel width as a function of downstream distance. Precipitation was scaled to elevation $(z)$ to account simply for orographic precipitation. The model operates on a staggered grid in which river slope, $d z / d x$ is calculated between $d x$-spaced nodes. 
We chose initial conditions to reflect a steady state channel profile, as such conditions likely existed prior to late Cenozoic uplift. As prominent steps in the modern profile correspond to resistant massive quartzite beds within metamorphic pendants, we employed contrasting $K$ values (ranging from $2.3 \times 10^{-14}$ to $3.5 \times 10^{-15}$ ) in these reaches. Using the steady state river profile as the initial condition, rock uplift of $\sim 1.5 \mathrm{~km}$ of rock uplift at the crest was accomplished at time $=0$ by westward tilting about a hinge line at $\mathrm{z}=0$; the elevation of the river was pinned at this point. Such tilting leads to increases in both $Q$, due to enhancement of orographic precipitation, and $d z / d x$, due to steepening of the channel gradient. The river profile was then allowed to evolve.

The river at the mountain front is most sensitive to changes in slope, and responds to tilting by initiating a knick zone at the mountain front that then propagates up the river profile. In our models the knick zone reaches the caves at ca. $5 \mathrm{Ma}, \sim 4$ m.y. after uplift is initiated. As the knick zone passes by the caves, incision rates are $>0.3 \mathrm{~mm} / \mathrm{yr}$; after it passes ca. $1 \mathrm{Ma}$, incision rates fall to $\sim 0.1 \mathrm{~mm} / \mathrm{yr}$. This latter rate is a factor of two to three higher than the late Quaternary incision rates we document from the caves. As this period corresponds to the largest of the Pleistocene glacial cycles, we explored the possibility that the channel bed was periodically mantled by glacially derived sediment, reducing the rate of erosion of the underlying bedrock. We mimicked this process in the model by reducing the incision efficiency, $K$, in a pattern that follows the last $10 \mathrm{~m} . \mathrm{y}$. of the $\delta^{18} \mathrm{O}$ curve of Zachos et al. (2001). Only when we combine both rock uplift and sediment mantling in the model does the incision rate history closely match that derived from the caves.

\section{REFERENCES}

Dunai, T. J., 2000, Scaling factors for production rates of in situ produced cosmogenic nuclides: a critical reevaluation: Earth and Planetary Science Letters, v. 176, p. 157-169.

Dunne, J., Elmore, D., and Muzikar, P., 1999, Scaling factors for the rates of production of cosmogenic nuclides for geometric shielding and attenuation at depth on sloped surfaces: Geomorphology, v. 27, p 3-11.

Kohl, C. P., and Nishiizumi, K., 1992, Chemical isolation of quartz for measurement of in-situ-produced cosmogenic nuclides: Geochemica et Cosmochemica Acta, v. 56, p. 3583-3587.

Stone, J. O., 2000, Air pressure and cosmogenic isotope production: Journal of Geophysical Research, v. 105, p. $23,753-23,759$.

Zachos, J., Pagani, M., Sloan, L., Thomas, E., and Billups, K., 2001, Trends, rhythms, and aberrations in global climate 65 Ma to present: Science, v. 292, p. 686-693. 